\title{
Maximum Hours Legislation and Female Employment: A Reassessment
}

\section{Citation}

Goldin, Claudia. 1988. Maximum Hours Legislation and Female Employment: A Reassessment. Journal of Political Economy 96(1): 189-205.

\section{Published Version}

http://dx.doi.org/10.1086/261531

\section{Permanent link}

http://nrs.harvard.edu/urn-3:HUL.InstRepos:2645471

\section{Terms of Use}

This article was downloaded from Harvard University's DASH repository, and is made available under the terms and conditions applicable to Other Posted Material, as set forth at http:// nrs.harvard.edu/urn-3:HUL.InstRepos:dash.current.terms-of-use\#LAA

\section{Share Your Story}

The Harvard community has made this article openly available.

Please share how this access benefits you. Submit a story.

Accessibility 


\section{Maximum Hours Legislation and Female Employment: A Reassessment}

\section{Claudia Goldin}

University of Pennsyluanua and Natomal Bureau of Economuc Research

The causes and consequences of state maximum hours legislation for female workers, passed from 1848 to the 1920 s, are found to differ from a recent interpretation. Although maximum hours legislation served to reduce scheduled hours in 1920, the impact was minimal. Curiously, the legislation appears to have operated equally for men. Legislation affecting only women was symptomatic of a general desire by labor for lower hours, and these lower hours were achieved in the tight, and otherwise special, World War I labor market. Most important, the restrictiveness of the legislation had no adverse effect on the employment share of women in manufacturing.

The development of . . state legislation on hours has tended to follow a very definite pattern. An insistent and persistent demand for general legislation to insure shorter hours for all led to the passage of general eighthour laws. When statutes of such unrestricted application proved unavailing, attempts at hours' regulation concentrated on specific classes of employees. [CAHILL (1932) 1968, p. 94]

State laws mandating daily and weekly maximum hours of work appeared as early as 1848, and by 1921 all but four states had passed such legislation. Half the states adopted their first laws during the

The comments of Stanley Engerman, David Gray, Ethel Jones, Peter Linneman, Robert Margo, the participants of the University of Illinois Labor Economics Seminar and those at the May 1986 University of California Conference "Searching for Security," and the cooperation of Elisabeth $M$. Landes are all gratefully acknowledged. Robert Whaples provided superlative research assistance, and the National Science Foundation provided the funding. A longer version of this paper was originally circulated as NBER Working Paper no. 1949 (Goldin 1986). 
initial two decades of this century, and 40 states passed some form of hours legislation during the second decade. While the precise number of hours and the details varied by state, one aspect was common to all: the laws applied almost exclusively to the employment of women. ${ }^{1}$ General hours legislation had been declared unconstitutional by several states and eventually by the Supreme Court in New York v. Lochner (1905), but in the now-famous case Muller v. Oregon (1908) the Court finally established the constitutionality of maximum hours legislation for women. At the time of their passage, maximum hours laws received mixed reviews. To their champions the laws would serve to protect women from their employers; however, others predicted that they would result in reduced female employment.

The motivation for and impact of protective legislation have received renewed attention. In her study of maximum hours legislation, Elisabeth Landes (1980) concluded that it greatly reduced hours worked per week by women in 1920 and lessened their employment share in manufacturing, the major covered sector. Furthermore, the reduction in employment was most pronounced among the daughters of the foreign-born, and the passage of this legislation was, by inference, supported by native-born, male manufacturing workers, who stood to gain the most.

This paper reassesses the interpretation of maximum hours legislation and introduces new information on its impact. The findings differ substantially from those of Landes. ${ }^{2}$ Although maximum hours legislation reduced scheduled hours, the impact was minimal and it operated equally for men. The reasons for this apparently curious result are clear from the epigraph. Legislation affecting only women was often symptomatic of a general desire by labor for lower hours, and these lower hours were achieved in the tight, and otherwise special, World War I labor market. Legislation affecting only women was but one way labor sought to build a coalition in support of reduced hours. ${ }^{3}$ It is important at the outset to point out that states that passed legislation did not always have lower scheduled hours; there is no

\footnotetext{
${ }^{1}$ Mississippi (in 1910) and Oregon (in 1920) passed legislation covering men, and the Georgia law covered all textile workers (see Cahill 1968). Many other states attempted to pass general legislation but were thwarted by various state supreme courts, except when the laws explicitly allowed contracts for more than the maximum number of hours, rendering them virtually useless.

${ }^{2}$ It should be noted that Jones's (1975) analysis of the impact of maximum hours legislation on hours of work concluded that it played no role in the decline in hours from 1909 to 1919.

${ }^{3}$ I have not yet explored whether labor was constrained by existing hours in the preWorld War I period. In her study of iron and steel, Shiells (1986) concluded that these workers were constrained. Reduced immigration in the early 1920 s lowered the median worker's supply of hours, but labor in the industry was insufficiently organized to effect change. The large reductions in hours of work in general over the 1909-19 period suggest that workers were constrained.
} 
relationship between scheduled hours of work by state in 1909 and subsequent legislation. ${ }^{4}$

Most important, the restrictiveness of the legislation had no effect on the employment share of women in manufacturing. Its restrictiveness was, on the contrary, associated with a positive impact on the employment share of women in sales (another covered sector). Finally, higher labor force participation of women across cities during the 1920s was strongly correlated with shorter hours of work per day, consistent with one time-series explanation for the increase in female market work and with recent cross-section evidence.

Some of the differences between my findings and those of Landes are rooted in different specifications, while some are founded in new evidence on hours of work. None of the differences between this paper and the Landes article detracts from the contribution of the original, which was to highlight an important and often forgotten part of the history of hours of work, female employment, and protective legislation.

The resolution of the impact of hours legislation is particularly relevant with the recent passage of comparable worth legislation and with renewed interest in the political economy of "rent-seeking" behavior. Various types of protective legislation, such as child labor laws, compulsory attendance, and pay equity, which were once viewed as humanitarian in origin, have also been reinterpreted as directly benefiting certain groups, but not the ones to which the legislation directly applied. ${ }^{5}$

Maximum hours legislation may be relevant, as well, to understanding the long-term decline in hours of work over the course of this century. The findings here concerning the relationship between the decline in male and female hours necessitate further study of the decline in hours in general. The average scheduled workweek in manufacturing fell by almost 9 hours from 1900 to 1920 , or by one full workday. ${ }^{6}$ Much of the decline occurred in the brief period from

4 The possibility that hours legislation was later passed in states in which hours had already declined, and therefore in which there was less opposition, was confronted and disproved by Landes. She found that "state differences in hours worked did not exist prior to legislation" $(1980$, p. $481, n .9)$. I have confirmed these results by a more direct test and have found that among the states that did not pass their first law before 1909 (28 states), those that passed their first law from 1909 to 1914 did not have lower scheduled hours in 1909 . However, these states did have hours lowered by 1.65 compared with the other states in 1919 , consistent with the analysis in this paper.

${ }^{5}$ On child labor laws in Britain, see Marvel (1977). Note that W. Landes and Solmon (1972) interpreted the passage of compulsory schooling legislation as coming after most children were in school for the legislated amount of time. Neither $E$. Landes nor I have been able to find convincing empirical evidence to support the hypothesis for the case of hours (see n. 4).

${ }^{6}$ Trends in actual hours are only slightly different from those in scheduled hours. Jones (1963), in a study of actual hours of work, found a decline of 7 hours from 1909 to 1919 . 
1916 to 1920 (U.S. Bureau of the Census 1975, ser. D-769, p. 168) during and just after an outpouring of state hours legislation and coinciding with generally favorable economic conditions and trade union strength.

\section{The Impact of Maximum Hours Legislation on Hours of Work}

Did maximum hours legislation have an impact on the scheduled hours of women and, if so, by how much? Landes (1980) explored this question with state-level data from the 1919 Census of Manufactures, which aggregated male and female employees and gave scheduled (not actual) hours of work per week for firms.

To separate the impact of hours legislation on male and female employees, an identity is estimated in which mean scheduled hours by state are regressed on the female share of employment in manufacturing (PMFF20), a dummy variable equal to one if the state passed a maximum hours law by 1914 interacted with the percentage female (PMFF20 $\times$ DUM), and several variables (South dummy $=\mathrm{SD}$, urbanization $=$ PURB) to account for differences in hours across states. By including only PMFF20 $\times$ DUM, the maximum hours law dummy multiplied by percentage female, the impact of hours laws is constrained to fall entirely on female employees. The coefficient on PMFF20 $\times$ DUM is then the decrease in the number of hours worked by women in states with hours legislation. ${ }^{7}$

A more general specification would also include the dummy variable (DUM), the coefficient of which is the decrease in the number of hours worked by men in states with hours legislation. Then the coefficient on PMFF20 $\times$ DUM is the difference in the decline in hours (due to legislation) of women compared with men, and the coefficient on the percentage female (PMFF20) is the difference between aver-

7 The identity is simply

$$
H=a_{f} H_{f}+\left(1-\alpha_{f}\right) H_{m}+\left(\alpha_{f} \times \mathrm{DUM}\right) \beta_{f} H_{f},
$$

where $H$ is average scheduled hours, $H_{f}$ is average scheduled hours for females in unconstrained states, $H_{m}$ is average scheduled hours for males in unconstrained states, DUM equals one if a state has a maximum hours law, $\alpha_{f}$ is the percentage of manufacturing employment that is female, and $\beta_{f}$ is the marginal impact of hours laws on mean female hours and is expected to be negative. Rewriting yields the estimated equation

$$
H=H_{m}+\left(H_{f}-H_{m}\right) \alpha_{f}+\left(H_{f} \beta_{f}\right)\left(\alpha_{f} \times \text { DUM }\right) \text {. }
$$

Thus the coefficient on $\alpha_{f}$ is the difference between female and male hours in unconstrained states, and the coefficient on $\alpha_{f} \times$ DUM is the decline in female hours in constrained states. 
TABLE 1

Impact of Hours Legislation on Scheduled Weekly Hours by State, 1920

\begin{tabular}{lcccc}
\hline \hline $\begin{array}{l}\text { Independent } \\
\text { Variables }\end{array}$ & $(1)$ & $(2)$ & $(3)$ & $(4)$ \\
\hline Constant & 53.3 & 53.6 & 54.4 & 54.7 \\
SD & $(69.1)$ & $(76.9)$ & $(86.4)$ & $(55.7)$ \\
& 1.72 & 1.55 & 1.69 & 1.73 \\
PURB & $(3.43)$ & $(2.72)$ & $(3.03)$ & $(3.01)$ \\
& -.05 & -.059 & -.058 & -.059 \\
PMFF20 & $(3.72)$ & $(3.81)$ & $(3.95)$ & $(3.87)$ \\
PMFF20 & .11 & .133 & .064 & .041 \\
DUM DUM & $(1.93)$ & $(2.20)$ & $(1.30)$ & $(.48)$ \\
$R^{2}$ & -.08 & -.101 & $\ldots$ & .035 \\
Number of & $(1.81)$ & $(1.99)$ & -1.47 & -1.82 \\
$\quad$ observations & $\ldots$. & $\ldots$ & $(2.55)$ & $(1.56)$ \\
& .67 & .61 & .63 & .63 \\
\hline
\end{tabular}

Sources.-Col 1: Landes (1980, p. 480). Cols. 2-4: Hours data (HRS19) are from the 1919 Consw of Manufactures, vol. 8; PMFF20, manufacturing employment data, are from the 1920 Census of Population, vol 4, DUM is from information in Landes (1980, table 1) and U.S. Women's Bureau (1931); PURB is from the 1920 Census of Population, vol. 1 .

Note-Dependent variable HRS 19 = mean scheduled hours in manufacturing in 1919 (mean = 52.2), SD = dummy varuable for southern states; PURB = petcentage of the state's population that was urban in 1920, PMFF20 = percentage of the manufacturing labor force that was female, DUM $=1$ if the state passed its first enforceable maximum hours law by 1914. The means of the (unweighted) independent vanables are. SD $=31$, PURB = 43.4, PMFF20 = 123 , DUM = 673. Absolute values of $t$-starisucs are in parentheses Note that none of the equations has been weighted to account for heteroscedastrity in estimaing an identity, however, see the text for a justificaion.

age hours for females and males in the unconstrained states. The constant term is the unconstrained value of male hours. ${ }^{8}$

Various hours equations estimated across states (and the District of Columbia) are presented in table 1 . Column 1 gives the results in Landes; column 2 reestimates the same equation following the variable construction in the original article and results in similar coefficients. Column 3 omits the interaction of the dummy variable with the percentage of manufacturing labor that was female but includes the dummy variable. Finally, column 4 contains the least constrained estimation.

Landes's estimation of the more restrictive equation indicated that hours legislation decreased scheduled hours of women by 8 per week. Note that 8 hours per week was 15 percent of mean scheduled hours

${ }^{8}$ The more general specification adds to that in $\mathbf{n} .7$ a term for the impact of hours legislation on male hours:

$$
H=\alpha_{f} H_{f}+\left(1-\alpha_{f}\right) H_{m}+\left(\alpha_{f} \times \mathrm{DUM}\right) \beta_{f} H_{f}+\left[\left(1-\alpha_{f}\right) \times \mathrm{DUM}\right] \beta_{m} H_{m} .
$$

Rewriting yields the estimated equation

$$
H=H_{m}+\left(H_{f}-H_{m}\right) \alpha_{f}+\left(H_{f} \beta_{f}-H_{m} \beta_{m}\right)\left(\alpha_{f} \times \mathrm{DUM}\right)+\left(H_{m} \beta_{m}\right) \mathrm{DUM} .
$$


per week, almost one full weekday of work. Furthermore, the coefficient on PMFF20 of 0.11 indicates that women working in states without maximum hours legislation worked a full 11 hours more per week than men did. It would be very surprising if states without restrictions had scheduled hours for women that exceeded those in covered states by a full weekday of work and if women in states without legislation worked the equivalent of over one full day more than men did. These conclusions, however, are not supported when a more general equation is estimated and when more disaggregated data are used.

Hours legislation served to decrease average (male and female) scheduled hours by about 1.5 per week, as can be seen by computing the average or by estimating the equation with the dummy variable not interacted, as in column $3 .{ }^{9}$ The constrained estimation puts the full burden of the legislation on female employment. Thus the reduction in female hours would have to be approximately 12 hours, which accounts for the estimate of 10.1 hours from column 2 .

Consider instead the estimation in column 4 , which also includes DUM. The estimated coefficients reverse the earlier findings and suggest an entirely new interpretation of hours legislation. Hours legislation is found to have had no differential impact on female hours. Instead, it reduced both male and female hours by about 1.8 hours.

One may rightly question whether these results have been produced by a misspecified model. ${ }^{10}$ Because scheduled hours in the manufacturing census are also listed by industry as well as by state, the decline in hours can be estimated for industries hiring only male workers. The findings from the identity have been confirmed by an estimation across states for an industry in which there were virtually no female employees-foundries-and for groups of other maleintensive industries, to be discussed below. In fact, the reduction in scheduled hours of foundry workers in states with maximum hours legislation (once again, that cover only women) was virtually identical to that from the full estimation in table $1 .{ }^{11}$

\footnotetext{
9 The percentage of the manufacturing labor force that was female was 12.3. Multiplying by the coefficient on PMFF20 $\times$ DUM from col. 2 gives 1.24 .

${ }^{10}$ As noted in the table, the equations were not corrected for possible heteroscedasticity problems inherent in estimating identities.

1 The results for the foundry data (when the variable definitions and constructions in table 1 are used) are, first for an unweighted sample and then for a weighted sample,

$$
\begin{aligned}
& \text { HRS19 }=54.9-.046 \text { PURB }-.095 S D-1.80 D U M, R^{2}=.38 ; N=44 \text {; } \\
& \text { (61.0) (2.70) (.13) (2.18) } \\
& \text { HRS19 }=55.1-.035 \text { PURB }-.348 S D-1.89 D U M, R^{2}=.32 ; N=44 \text {. } \\
& \text { (52.9) (2.04) (.42) } \quad(2.16)
\end{aligned}
$$

(Source: 1919 Census of Manufactures, vol. 8; see also table 1.) Five states had insufficient employment in foundries to be listed in the census. 
These findings suggest that protective legislation for women was associated with a decline in hours of work for men. The reason for this apparently peculiar result is, as suggested by the epigraph, that laborers in states that passed protective legislation for women had sentiments for decreased hours of work in general. They were able to lobby more forcefully for laws covering women whose plight appealed to legislators, and state supreme courts did not, in general, challenge laws that applied only to women. Note that the analysis does not assess whether women were "hours constrained" in the presence of legislation or whether men and women were hours constrained prior to the large declines in hours from 1909 to 1919. Those are separate and difficult issues.

The proposition that protective legislation was passed in states in which male labor lobbied vigorously for general hours reductions can be tested by using disaggregated data by industry for 1914 and 1919 from the 1920 Census of Manufactures (vol. 9). For each state the two largest female-intensive industries and the two largest male-intensive industries were selected. In the former, females were, on average, about 50 percent of the labor force; in the latter, however, they were less than 2 percent of the labor force. Those in male-intensive industries, therefore, could not have viewed female labor as a direct threat; these industries (e.g., lumber, foundries, steam car railroads) never contained many female employees (if any at all).

Define MDIFF to be average scheduled hours for males in 1919 minus average scheduled hours for males in 1914 and FDIFF to be the same for females. Let LIM 14 be the existing weekly hours limit in 1914 (with the zero limit set equal to 66 hours). Then

$$
\begin{gathered}
\text { MDIFF }=-20.24+.256 \text { LIM } 14+\underset{(3.65)(3.06) \quad}{1.39 S D}+.0362 \text { PURB, } \\
R^{2}=.22,
\end{gathered}
$$

is obtained when estimated across the 49 states (including District of Columbia) and indicates that the 1914 hours limit is positively related to the decline in hours for males from 1914 to 1919. Therefore, the lower the limit, the greater the decline in male hours. However, for females

$$
\begin{aligned}
& \text { FDIFF }=4.27-.090 \text { LIM14 }+.109 \text { SD }-.0569 \text { PURB, } \\
& \text { (.85) (1.19) } \\
& \text { (.14) } \\
& R^{2}=.17,
\end{aligned}
$$

indicates that the decline in female hours was not related to the existing 1914 limit. These results, taken together, suggest that labor in male-intensive industries lobbied effectively for hours limits for fe- 
males in states in which male laborers were ultimately successful at lowering their own hours. In many of these states the dominant maleintensive industry was lumber, in which the Wobblies led successful strike activity in the unique World War I environment (see Hidy, Hill, and Nevins 1963, pp. 332-51). Organized labor in male-intensive industries may have cared about female hours of work because the more laborers working shorter hours, the more it would become the norm for all. ${ }^{12}$

A further complication with the statement that hours legislation substantially reduced hours of work is that the manufacturing data refer to scheduled, not actual, hours. It is actual hours worked that are at issue. Data on actual hours of work by women are unavailable on a national basis for this period of time but exist for various states in the surveys of the Women's Bureau. ${ }^{13}$ Scheduled weekly hours, actual weekly hours, and the hours laws in effect at the time of the survey are given in table 2 for states with complete information in the Women's Bureau bulletins. The data show that mean actual hours were far more similar across states than were mean scheduled hours. While states with the least restrictive hours legislation had the highest scheduled hours per week, actual hours per week worked by female employees in manufacturing and mercantile establishments were far lower than average scheduled hours. In Missouri and South Carolina, which had among the highest scheduled hours, actual weekly hours worked were only 82 percent of scheduled hours. In Illinois, New Jersey, and Rhode Island, which had among the lowest scheduled hours, the ratio was over $\mathbf{9 0}$ percent. The elasticity of actual hours with respect to scheduled hours was $0.82 .{ }^{14}$ Therefore, the difference in actual hours between states with legislation and those without was probably even less than what the difference in scheduled hours indicates.

12 While there is no implication that female employees were unconstrained in states with maximum hours legislation, I have not been able to estimate a decline in their hours (for the female-intensive industry sample) in states with restrictions (an exercise similar to that in table 1). Male-intensive industry hours, however, were lower by 1.4 in states with legislation, consistent with the foundry data.

13 These states are not, however, a random sample; the Women's Bureau directed its efforts at states with higher than average scheduled hours that had requested surveys to assist in evaluating their legislation or in formulating minimum wage standards. The Women's Bureau did include several states (such as New Jersey and Ohio) that had restrictive hours legislation. Even with the biases in the sample, the unweighted mean of scheduled hours is $\mathbf{5 1 . 2}$ or exactly $\mathbf{1}$ hour below the unweighted mean of scheduled hours in the 1919 Census of Manufactures, which is the average for males and females.

${ }^{14}$ An equation estimated across the 15 states in table 2 yields

$$
\log \text { Actual Hours }=.576+.821 \log \text { Scheduled Hours; }
$$

$R^{2}=.60$; corrected $R^{2}=.57 ; t$-statistics are in parentheses. 
TABLE 2

Mean Scheduled Hours and Actual Hours Worked, gy Selected States, 1920s

\begin{tabular}{lcccc}
\hline \hline & $\begin{array}{c}\text { Scheduled } \\
\text { Hours } \\
\text { State (Survey Date) }\end{array}$ & $\begin{array}{c}\text { Actual } \\
\text { Hours } \\
(1)\end{array}$ & $\begin{array}{c}\text { (2)/(1) } \\
(3)\end{array}$ & $\begin{array}{c}\text { Hours Law } \\
\text { in Effect } \\
\text { Daily/Weekly } \\
(4)\end{array}$ \\
\hline Alabama (1924) & 53.9 & 46.4 & 86.1 & none \\
Arkansas (1922) & 51.5 & 47.7 & 92.6 & $9 / 54$ \\
Delaware (1924) & 50.4 & 41.1 & 81.5 & $10 / 55$ \\
Georgia (1920) & 55.5 & 47.9 & 86.3 & $10 / 60^{*}$ \\
Illinois (1924) & 49.0 & 44.7 & 91.2 & $10 /$ none \\
Kansas (1920) & 43.4 & 37.7 & 86.9 & $8 / 55$ \\
Kentucky (1921) & 51.7 & 45.0 & 87.0 & $10 / 60$ \\
Mississippi (1925) & 55.6 & 49.8 & 89.6 & $10 /$ none \\
Missouri (1922) & 53.1 & 43.5 & 81.9 & $9 / 54$ \\
New Jersey (1922) & 48.4 & 44.3 & 91.5 & $9 / 50$ \\
Ohio (1922) & 48.4 & 43.3 & 89.5 & $9 / 50$ \\
Oklahoma (1924) & 51.1 & 44.4 & 86.9 & $9 / 54$ \\
Rhode Island (1920) & 49.0 & 46.0 & 93.9 & $10 / 54$ \\
South Carolina (1921/22) & 54.6 & 44.9 & 82.2 & $10 / 55 / 60^{\ddagger}$ \\
Tennessee (1925) & 52.8 & 48.7 & 92.2 & $10.5 / 57$ \\
\hline Soungt & & & &
\end{tabular}

SourCE.--U.S. Women's Bureau (1919-27)

- Applies only to women working in cotton and woolen mills.

+ Data are for whice women only.

* 55 hours applies to textile factories; 60 hours elsewhere.

The close resemblance of the hours equation in table 1 to that in the original article indicates that the variables used are nearly identical. Thus the next stage of the empirical work, that on employment, using an almost identical set of variables should produce similar results. That, however, is not the case.

\section{The Impact on Employment: Theoretical Underpinnings and Empirical Results}

The impact of maximum hours legislation on the employment of women in the covered sector provided the key result in the Landes article. The estimation was motivated by a model of a labor market that predicted, under the most reasonable parameter values, that the female share of the covered sector would decline with effective maximum hours legislation.

Landes posited a model of labor hours in which individuals choose hours of work $\left(h_{i}\right)$, say per week, as a function of their hourly wage $(w), h_{i}=w^{\epsilon_{i}}$, and then choose to supply their labor $\left(L_{i}\right)$, say in labor days per week, as a function of their weekly earnings $\left(w h_{i}\right), L_{t}$ $=\left(w h_{i}\right)^{\epsilon_{1}}$, where $i=$ male $(m)$ or female $(f)$ workers. Workers are perfect substitutes for each other, and thus the wage is the same for 
both groups. Total hours of labor services, $S=\Sigma h_{i} L_{i}$, are identical, in equilibrium, to firm demand: $D=w^{-\eta}$. Effective maximum hours legislation for females alters the equilibrium in two manners: the elasticity of female hours with respect to the wage $\left(\epsilon_{h_{f}}\right)$ automatically becomes zero, and hours of work for females are reduced if the constraint is binding. The effects of the reduction in female hours on the total supply of hours, the wage, male labor, male hours, and female labor are given by $d S / d h_{f}>0, d w / d h_{f}<0, d L_{m} / d h_{f}<0, d h_{m} / d h_{f}$ $<0$, and $d L_{f} / d h_{f} \geqq 0$.

Thus all effects are unambiguous in sign except for that on female labor, which is the derivative of interest. It depends on the relationship between the elasticity of demand for labor hours plus an elasticity-weighted male labor force share and the female labor force share, $\left(\eta+\epsilon_{m}^{\prime} s_{m}-s_{f}\right) \gtreqless 0 .{ }^{15}$ As Landes points out, the most reasonable parameter estimates yield a positive impact. The female labor force in the covered sector would decline with effective maximum hours legislation.

This key result was tested (and affirmed) in the Landes article by estimating the impact on the female share of the manufacturing labor force of hours legislation. Although the empirical results obtained by Landes are consistent with the predictions of the model, I will demonstrate that the results are highly sensitive to a change in the construction of a key variable. The new construction is, I believe, more appropriate given the legislation and the limitations of the available data. The estimation with the changed variable can be better explained by a slightly revised model, in which female labor supply, in days worked per week, increases with reduced hours worked per day. ${ }^{16}$ The possibility that maximum hours laws could have expanded female employment should not be surprising. It has been frequently asserted that female labor force participation rates rose over the long run because scheduled hours of work per day declined, enabling women with responsibilities at home to work more days. ${ }^{17}$

Alternatively, the amended results can be understood within the context of the related decline in the work hours of male manufactur-

${ }^{15}$ The term $\epsilon_{m}^{\prime}=\epsilon_{L_{m}}+\epsilon_{h_{m}}+\left(\epsilon_{L_{m}} \times \epsilon_{h_{m}}\right)$, and $s_{t}=L_{i} h / S$.

16 This model is presented in a longer version of this paper (Goldin 1986) and is supported with evidence on the relationship between scheduled hours per day and days worked per week from Women's Bureau bulletins. These data suggest that women in states with high scheduled hours per day reduced the number of days they worked per week and that hours reductions per day served to increase the number of days worked per week.

${ }^{17}$ As Durand (1948, p. 118) noted: "The secular decrease in weekly hours of work is perhaps almost as important as the change in occupational composition of the demand for labor, as a factor in the increasing employment of women. The length of the working week is especially important in connection with the availability of married women for jobs." 
ing laborers. Had hours of work not declined for men, the impact of the legislation on the female employment share might have been greater.

In the employment equation estimated by Landes, the dependent variable was the percentage of the total manufacturing labor force that was female in 1920 (PMFF20), and the key independent variable accounted for the degree of restrictiveness of the state's maximum hours legislation (REST). Other variables were included to account for differences in the demand for or supply of female workers, such as urbanization, region, and a lagged employment share in manufacturing capturing a host of relevant factors.

The restrictiveness variable measures the percentage of the state's manufacturing labor force in 1909 that worked (in actuality, the percentage working in establishments that had scheduled hours) over the legal maximum in effect in 1914. The variable accounts for prior conditions and gives the proportion of the labor force in 1909 that would be constrained by the hours legislation passed by 1914 . Note that the restrictiveness variable is highly appropriate for this exercise. It is superior to a simple dummy variable indicating whether or not a state passed an hours law sometime between the year of the dependent variable (1920) and that of its lagged value (1900). Landes also included a dummy variable (here DUM1905-14) if a state passed its first enforceable maximum hours law between 1905 and 1914 .

Landes's estimated regression, given in column 1 of table 3, indicates that states with more restrictive legislation had a lower female employment share in manufacturing. Further estimations by Landes indicate that most of the decline in the employment share occurred for the daughters of the foreign-born and for foreign-born women. ${ }^{18}$ These results provided persuasive evidence that hours legislation was passed under the guise of humanitarian concern through the efforts of labor groups and others that stood to gain the most from restricting the employment of immigrant women and their daughters.

Note, however, the other regressions for the manufacturing sector appearing in table 3 . These were estimated on identical variables by state, most of which were also in the table 1 estimation. Unlike those in table 1 , there is little relationship between my results and those of Landes. Most important, the coefficient on the restrictiveness variable, here called WKREST, is generally positive but insignificant and that on the hours legislation dummy variable is negative and barely significant. These results are relatively robust to restricting the sample

\footnotetext{
${ }^{18}$ Note that in the estimation for the daughters of the foreign-born, Landes got a more significant coefficient on REST (her table 3, p. 487) than in the estimation for all women.
} 
TABLE 3

Effzct of Hours Legislation on the Employment Share of Women in Manufacturing and Sales, 1920

\begin{tabular}{|c|c|c|c|c|c|}
\hline $\begin{array}{l}\text { Independent } \\
\text { Variables }\end{array}$ & $\begin{array}{c}\text { PMFF20 } \\
\text { (Landes) } \\
\text { (1) }\end{array}$ & $\begin{array}{l}\text { PMFF20 } \\
\text { (2) }\end{array}$ & $\begin{array}{c}\text { PMFF20 } \\
\text { (3) }\end{array}$ & $\begin{array}{c}\text { PMFF20 } \\
\text { (Manufacturing) } \\
(4)\end{array}$ & $\begin{array}{l}\text { PSF20 } \\
(5)\end{array}$ \\
\hline Constant & $\begin{array}{l}-.00168 \\
(1.11)\end{array}$ & $\begin{array}{l}-.013 \\
(1.28)\end{array}$ & $\begin{array}{l}-.027 \\
(2.02)\end{array}$ & $\begin{array}{r}.041 \\
(3.53)\end{array}$ & $\begin{array}{r}.150 \\
(6.14)\end{array}$ \\
\hline EMP $_{-1}$ & $\begin{array}{c}.79 \\
(9.66)\end{array}$ & $\begin{array}{l}.753 \\
(11.4)\end{array}$ & $\begin{array}{l}.804 \\
(10.4)\end{array}$ & $\begin{array}{l}.829 \\
(13.9)\end{array}$ & $\begin{array}{r}.772 \\
(8.26)\end{array}$ \\
\hline SD & $\begin{array}{l}.0005 \\
(.06)\end{array}$ & $\begin{array}{l}.010 \\
(1.16)\end{array}$ & $\begin{array}{l}.014 \\
(1.52)\end{array}$ & $\begin{array}{l}.007 \\
(.72)\end{array}$ & $\begin{array}{c}-.006 \\
(.56)\end{array}$ \\
\hline PURB & $\begin{array}{l}.0005 \\
(2.26)\end{array}$ & $\begin{array}{l}.0003 \\
(1.44)\end{array}$ & $\begin{array}{l}.0004 \\
(1.81)\end{array}$ & $\begin{array}{c}-.0001 \\
(.48)\end{array}$ & $\begin{array}{l}-.0005 \\
(2.52)\end{array}$ \\
\hline DUM1905-14 & $\begin{array}{c}-.0012 \\
(.14)\end{array}$ & $\begin{array}{l}-.0157 \\
(1.83)\end{array}$ & $\begin{array}{l}-.0178 \\
(1.87)\end{array}$ & $\begin{array}{l}-.0130 \\
(1.23)\end{array}$ & $\begin{array}{c}-.0072 \\
(.82)\end{array}$ \\
\hline REST & $\begin{array}{l}-.0253 \\
(1.49)\end{array}$ & $\ldots$ & $\cdots$ & ․ & $\cdots$ \\
\hline WKREST & $\ldots$ & $\begin{array}{l}.0181 \\
(1.39)\end{array}$ & $\begin{array}{l}.0125 \\
(.86)\end{array}$ & $\begin{array}{l}.0181 \\
(1.12)\end{array}$ & $\begin{array}{l}.0215 \\
(1.63)\end{array}$ \\
\hline$R^{2}$ & .83 & .86 & .84 & .90 & .79 \\
\hline $\begin{array}{l}\text { Number of } \\
\text { observations }\end{array}$ & 41 & 49 & $41^{*}$ & 41 & 41 \\
\hline
\end{tabular}

Solreces. - Col. 1: Landes (1980, p. 484) Cols. 2-5. DUM1905-14 is constructed from data un Landes (1980, table 1) and U.S. Women's Bureau (1931) and was altered for estumation of col. 5; WKREST is constructed from the 1909 Census of Manufactures, vol. 8, and U.S. Women's Bureau (1931); EMP -1 is from U.S. Bureau of the Census (1904) and the 1910 Census of Population, vol. 4; PMFF20 and PSF20 are from the 1920 Census of Population, vol. 4; PMFF20 and EMP -1 for col. 4 are from the 1909 Census of Manufactures, vol. B, and the 1919 Census of Manufactures, vol. 8; PURB is for 1920 and is from the 1920 Census of Population, vol. 1.

NotE.-For the dependent variables, the mean of PMFF20 is .123 (.144 for col. 4); the mean of PSF20 is .333. PMFr20 = female employment share of manufacturing in 1920; PSF20 = female employment share in sales (zalespersons and clerks in stores) in 1920; EMP $-1=$ female employment share in manufacturing (sales for col. 5) in 1900 (1910 for sales), DUM 1905-14 = 1 if first enforceable maximum bours law in manufacturng (sales for col. 5) was passed from 1905 to 1914; WKREST (REST) = proportion of employees in 1909 who worked over the naximum number of weekly hours (for REST it is the daily lunt times six) in effect in 1914 (see text). Col. 1 drvides all coefficients by 100 (except EMP - 1) because the numbers in Landes express the share as a percentage. Ordunary least squares estimation was used for consustency with Landes. A weighted logit transformation yields almost identical sopes around the mean for the 48 states and District of Columbia and the nonmountann sample. Means for the entire 48 states and Distract of Columbia are: EMP $-1,156 ;$ SD, .306; PURB, 43.4; DUM1905-14, .286; WKREST, .362 .

- The eight mountain states are excluded for consistency with the Landes estimation.

to the $\mathbf{4 0}$ states (and District of Columbia) that are highlighted in the original article (i.e., excluding eight mountain states having few manufacturing workers), to weighting the regression by the square root of manufacturing employment in the state (not included in the table), and to estimating a (weighted) logistic transformation of the dependent variable (also not in the table). ${ }^{19}$

19 The original paper focused on the impact of hours legislation on the employment of native-born, foreign-parentage women and foreign-born women. The results of these estimations had yielded larger and more statistically significant coefficients than in the entire sample. My attempt to replicate these results did not yield significant effects on the key variable, WKREST. These equations have been estimated across the 41 (nonmountain) states (including District of Columbia) used in the original article: 
The source of the difference is the computation of the restrictiveness variable (termed REST by Landes and WKREST here). Many states passed weekly hours laws that were more restrictive than the daily limit times six. The REST variable in the original article was computed using a weekly restriction that was always six times the daily restriction even for states with lower weekly limits, despite the fact that the 1909 data used to create REST were for weekly scheduled hours. That procedure produced estimates that differ from those using the weekly legislation in 12 states (or one-quarter of the sample), including every New England state, Pennsylvania, Ohio, and Delaware. The WKREST variable differs from the REST variable, on average, by a factor of 10 across the 12 states.

Although the WKREST variable is not significant in the new estimation and is even positive, not negative, the DUM1905-14 variable is negative and barely significant. ${ }^{20}$ States that passed their first hours law between 1905 and 1914 were latecomers and may have been different for other reasons. The PMFF20 variable uses data on occupations from the population census, not the manufacturing census, because only the population census differentiated workers by nativity. The population census, however, included nonfirm manufacturing workers and generally overstated manufacturing employment, particularly in the less developed states. In many of the latecomer states, most of the female manufacturing workers in the population census were dressmakers. By 1920 the services of these workers had often been replaced by factory-produced goods. The estimation in column

native-white, foreign-parentage (NF) women as a share of all NF workers in the manufacturing labor force equals

$$
\begin{aligned}
& -.0060+.849 \mathrm{EMP}_{-1}-.0263 \mathrm{SD}+.0008 \mathrm{PURB} \\
& \text { (3.23) (10.2) (2.24) (2.82) } \\
& -.0252 D U M 1905-14+.0034 \text { WKREST; } \\
& \text { (2.07) (.18) } \\
& R^{2}=.87 ; N=41 ; \text { mean of dependent variable }=.165 \text {; }
\end{aligned}
$$

foreign-born (FB) women as a share of all FB workers in the manufacturing labor force equals

$$
\begin{aligned}
& -.0087+.753 \mathrm{EMP}_{-1}+.0019 \mathrm{SD}+.0003 \mathrm{PURB}
\end{aligned}
$$

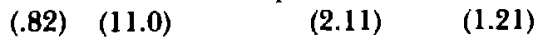

$$
\begin{aligned}
& \text { - .0083DUM1905-14 - .0036WKREST; } \\
& \text { (.84) } \\
& \text { (.23) } \\
& R^{2}=.85 ; N=41 ; \text { mean of dependent variable }=.085 .
\end{aligned}
$$

(Sources: See table 3 and the 1920 Census of Population, vol. 4, for independent variables.)

${ }^{20}$ It should also be pointed out that removing the WKREST variable reduces the significance of the DUM1905-14 variable and lowers its coefficient in absolute value for all estimations. 
4 uses the manufacturing census data, and the coefficient on DUM1905-14, while still negative, is not significant. It is possible that some of the latecomer states had male labor forces that desired to reduce female employment, but the evidence is not strong. ${ }^{21}$

Focus now on a different equation in table 3 , one in which the dependent variable is the percentage of sales (not clerical) labor force that is fernale in 1920 (PSF20), as in column 5. Retail trade was also covered by maximum hours legislation, and in some states mercantile establishments were covered before manufacturing firms. An equation similar to that for the manufacturing sector was estimated for the sales sector with results that are very different. The female share of sales employment actually increased in states having more restrictive hours legislation. ${ }^{22}$ It should be emphasized that the decline in the female share of the manufacturing labor force during the 1900-1920 period did not mark a new trend. ${ }^{23}$ The female share of the manufacturing labor force had been declining for decades preceding maximum hours legislation, and the share probably peaked as early as the 1840s (see Goldin and Sokoloff 1982). Female employment in the sales sector, however, began to increase during the first decades of this century. The coefficient on WKREST suggests that maximum hours legislation, by reducing daily hours in the sales sector, may have increased the employment share of females. Thus while the restrictiveness of maximum hours legislation may have had little or no effect on female employment in manufacturing, it may have had a positive effect on female employment in sales.

The variables used thus far to measure the employment effect are the shares of women in a particular sector. The fernale labor force participation rate could also have been altered by hours legislation. Under the gainful worker definition, participation was probably related to the average number of days an individual worked (see Goldin 1987). Thus decreasing hours of employment could have increased

${ }^{21}$ Baker ([1925] 1968, chap. 6) contains several examples of industries in which male workers probably benefited from maximum hours legislation. My claim here is that, on average, female employment did not decline with the restrictiveness of the legislation but that female employment in certain industries and in certain states may have been adversely affected.

${ }^{22}$ Note that the restrictiveness variable was computed for the manufacturing labor force because scheduled hours for mercantile establishments were not available. The Women's Bureau bulletins cited in table 2 indicate, however, that there was relative homogeneity within states across manufacturing and sales hours schedules. Note, as well, that the estimation includes the percentage of sales workers who were female in 1910 rather than the percentage in 1900 , as in the manufacturing estimations. While it would have been more appropriate to use 1900 , only 1910 data were available for sales workers.

${ }^{29}$ The decline is evident only in the population census data. The manufacturing census data show an increase in the fernale share. 
days worked and the labor force participation rate. To assess the proposition, a relationship was estimated across large urban areas (cities having over 100,000 persons) in various states between the labor force participation rate of a group of women, for example, native-born white married women, and mean scheduled hours of work in manufacturing.

Constant elasticity equations were estimated for white women of native-born, foreign-born, and native-born of foreign-born parents, separately for married women and all marital statuses. The coefficients on hours per day in all equations are negative and substantial, indicating that shorter hours were associated with higher participation rates. The result holds across all subgroups of white women, but it is strongest, by nativity, for married women. ${ }^{24}$ The generally larger elasticities for married women indicate that days worked per year were more responsive to scheduled hours per day for those with greater home responsibilities. This result is similar to that in King (1978), who found that labor force participation among married women with children in 1970 was higher in cities in which men worked fewer hours.

\section{Summary Comments}

The causes and consequences of maximum hours legislation have been explored and found to differ from the interpretation presented by Landes. In particular, hours declined for men as well as for women in states with hours legislation, and the employment share of women in manufacturing did not decrease with the restrictiveness of the

${ }^{24}$ The elasticities of labor force participation with respect to mean scheduled hours of work in manufacturing in 1920 were computed using only one additional independent variable, the southern dummy (SD). At present insufficient wage data are available to include in the estimation. (Dependent variable is the log labor force participation rate.)

\begin{tabular}{lcccccc}
\hline \hline & NN-A & NN-M & NF-A & NF-M & FB-A & FB-M \\
\hline log HRS19 & -.719 & -1.11 & -1.67 & -2.60 & -2.54 & -2.59 \\
& $(1.18)$ & $(1.07)$ & $(2.23)$ & $(3.35)$ & $(3.22)$ & $(2.68)$ \\
SD & -.100 & -.234 & -.199 & -.211 & .017 & .050 \\
& $(1.48)$ & $(2.03)$ & $(2.40)$ & $(1.72)$ & $(.20)$ & $(.47)$ \\
Constant & 6.31 & 6.77 & 10.12 & 12.36 & 12.97 & 12.18 \\
& $(2.63)$ & $(1.65)$ & $(3.43)$ & $(2.84)$ & $(4.19)$ & $(3.21)$ \\
$R^{2}$ & .23 & .29 & .47 & .41 & .34 & .24 \\
Mean & 32.0 & 10.6 & 33.3 & 8.2 & 19.7 & 7.5 \\
\hline
\end{tabular}

NN = native-born, native parentage; $N F=$ native-born, foreign parentage; FB $=$ foreign-born; $\mathbf{A}=$ all marital statuses; $\mathbf{M}=$ married. Equations were estimated across the large urban areas of 31 states. Absolute values of $t$-statistics are in parentheses. (Sources: See table 1 and Hill 1929.) 
legislation. Indeed, the employment share of women in another covered sector, sales, rose with increasing restrictiveness, and female labor force participation rates were positively correlated with shorter hours. ${ }^{25}$

This work has raised further questions about hours legislation and the long-term decline in the workday and workweek in America. I have suggested the reasons for the relationship between the decline in hours worked by men and legislation protecting women, but it is still not clear what precise mechanisms operated to reduce hours of work for all.

\section{References}

Baker, Elizabeth Faulkner. Protective Labor Legislation: With Special Reference to Women in the State of New York. 1925. Reprint. New York: AMS, 1969.

Cahill, Marion Cotter. Shorter Hours: A Study of the Movement since the Civil War. 1932. Reprint. New York: AMS, 1968.

Durand, John D. The Labor Force in the United States, 1890-1960. New York: Soc. Sci. Res. Council, 1948.

Goldin, Claudia. "Maximum Hours Legislation and Female Employment in the 1920s: A Reassessment." Working Paper no. 1949. Cambridge, Mass.: NBER, June 1986.

- "The Female Labor Force and American Economic Growth, 18901980." In Long-Term Factors in American Economic Growth, edited by Stanley L. Engerman and Robert Gallman. Chicago: Univ. Chicago Press (for NBER), 1987.

Goldin, Claudia, and Sokoloff, Kenneth. "Women, Children, and Industrialization in the Early Republic: Evidence from the Manufacturing Censuses." J. Econ. Hist. 42 (December 1982): 741-74.

Hidy, Ralph W.; Hill, Frank Ernest; and Nevins, Allan. Timber and Men: The Weyerhaeuser Story. New York: Macmillan, 1963.

Hill, Joseph A. Women in Gainful Occupations, 1870 to 1920. Census Monographs no. 9. Washington: Government Printing Office, 1929.

Jones, Ethel B. "New Estimates of Hours of Work per Week and Hourly Earnings, 1900-1957." Rev. Econ. and Statis. 45 (November 1963): 374-85.

- "State Legislation and Hours of Work in Manufacturing." Southern Econ. J. 41 (April 1975): 602-12.

King, Allan G. "Industrial Structure, the Flexibility of Working Hours, and Women's Labor Force Participation." Rev. Econ. and Statis. 60 (August 1978): 399-407.

Landes, Elisabeth M. "The Effect of State Maximum-Hours Laws on the Employment of Women in 1920." J.P.E. 88 (June 1980): 476-94.

Landes, William M., and Solmon, Lewis C. "Compulsory Schooling Legisla-

${ }^{25}$ One finding that is not in dispute is the relationship between the passage of maximum hours laws and union strength, which Landes found to be a prime determinant of the restrictiveness of legislation as of 1914 (using the state's unionization ranking in 1964). My interpretation of this result, however, is that unions were less interested in restricting female employment than they were in reducing hours in all industries, especially male-intensive ones such as lumber and steel. 
tion: An Economic Analysis of Law and Social Change in the Nineteenth Century." J. Econ. Hist. 32 (March 1972): 54-91.

Marvel, Howard P. "Factory Regulation: A Reinterpretation of Early English Experience." J. Law and Econ. 20 (October 1977): 379-402.

Shiells, Martha. "Hours of Work and Shiftwork in the Early Industrial Labor Markets of Great Britain, the United States, and Japan." Ph.D. dissertation, Univ. Michigan, 1986.

U.S. Bureau of the Census. Twelfth Census of the United States 1900. Special Report. Occupations at the Twelfth Census. Washington: Government Printing Office, 1904.

Historical Statistics of the United States: Colonial Times to 1970. Washington: Government Printing Office, 1975.

U.S. Women's Bureau. Women in [State] Industries: A Study of Hours and Working Conditions. Washington: Government Printing Office, 1919-27, various bulletins.

Chronological Development of Labor Legislation for Women in the United States. Women's Bureau Bulletin no. 66-II. Washington: Government Printing Office, December 1931. 